\title{
Kidney histology in streptozotocin-induced diabetic male Wistar rats treated with combined extract of temulawak rhizome and belimbing wuluh fruit
}

\author{
KARTIAWATI ALIPIN", EMA PURNAMA SARI, MADIHAH, TIA SETIAWATI, \\ NINING RATNINGSIH, DESAK MADE MALINI \\ Department of Biology, Faculty of Mathematics and Natural Sciences, Universitas Padjadjaran. Jl. Raya Bandung-Sumedang Km. 21 Jatinangor, \\ Sumedang 45363, West Java, Indonesia. Tel./Fax. +62-22-7796412, ”email: kartiawati@unpad.ac.id
}

Manuscript received: 15 Juni 2017. Revision accepted: 29 August 2017.

\begin{abstract}
Alipin K, Sari EP, Madihah, Setiawati T, Ratningsih N, Malini DM. 2017. Kidney histology in streptozotocin-induced diabetic male Wistar rats treated with combined extract of temulawak rhizome and belimbing wuluh fruit. Nusantara Bioscience 9: $312-317$. Complications that are occurred in patients with Diabetes Mellitus usually followed by kidney damage. Temulawak (Curcuma xanthorrhiza Roxb.) and belimbing wuluh (Averrhoa bilimbi L.) were traditionally used to decrease blood glucose level. Thus, they were potential as antidiabetic drugs. This study aimed to evaluate the combination of ethanol extracts of temulawak rhizome and belimbing wuluh fruit in repairing kidney damage in diabetic male Wistar rats induced by streptozotocin (STZ). An experimental method using a completely randomized design that consist of seven treatments with three replications. Six treatment groups were

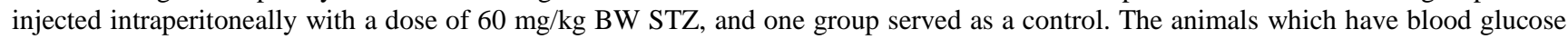
level $2200 \mathrm{mg} / \mathrm{dl}$ were stated as diabetic. Furthermore, the animals were treated orally with single extract i.e. temulawak $17.5 \mathrm{mg} / \mathrm{kg}$ BW or belimbing wuluh $750 \mathrm{mg} / \mathrm{kg} \mathrm{BW}$ and combined extracts 383.75 or $767.5 \mathrm{mg} / \mathrm{kg} \mathrm{BW}$, as well as glibenclamide $0.45 \mathrm{mg} / \mathrm{kg}$ BW as reference, including diabetic rat as positive control and non-diabetic rat as negative control. The results showed that combine extract at dose of $383.75 \mathrm{mg} / \mathrm{kg}$ BW treatment repaired the kidney histology, i.e., glomerular diameter and Bowman space width, as well as significantly decreased the necrosis percentage of proximal tubular in diabetic rat compared with positive control group ( $\mathrm{p}<0.05$ ). In conclusion, the combined extract of temulawak rhizome and belimbing wuluh fruit has potent to cure renal failure in diabetic rats induced by streptozotocin.
\end{abstract}

Keywords: Averrhoa bilimbi, Curcuma xanthorrhiza, kidney, streptozotocin

\section{INTRODUCTION}

Diabetes Mellitus (DM) is a metabolic disease caused by the inability to produce any or enough insulin which results in elevated blood glucose level. In a diabetic condition, the body does not properly process food to be used as energy, because there were combinations of various disturbances in the body's metabolic system due to chronic hyperglycemia conditions associated with abnormal metabolism of carbohydrates, fats, and proteins (World Health Organization 1999). The typical symptoms of diabetes are polyuria, polydipsia, polyphagia, which are accompanied by hyperglycemia condition in which the plasma glucose concentration is greater than $200 \mathrm{mg} / \mathrm{dL}$ $(11.1 \mathrm{mmol} / \mathrm{L})$, and the fasting glucose concentration is 126 $\mathrm{mg} / \mathrm{dL}$ (7.0 mmol/L) (Cooke and Plotnick 2008). Diabetes caused serious complications including retinopathy that leads to blindness, nephropathy which leads to kidney failure, neuropathy which leads to impotence, diabetic foot disorder, as well as macrovascular complications including cardiovascular disease (WHO 2016). In parallel with the increase of diabetes, an increase in the prevalence of diabetic nephropathy has been noted (Ritz and Zeng 2011). Damage to the kidneys (diabetic nephropathy) occurs because of the damage to the blood vessels in the kidney, primarily in the glomerulus that results in kidney structure changes and disruption of its function (Ritz et al. 2000). International Diabetes Federation (IDF) in 2012 stated that $4.8 \%$ of Indonesians were diagnosed with diabetes. Diabetic nephropathy is one of the most important DM complications, which is marked with histological kidney lesions that may vary from nodular or diffuse glomerulosclerosis to tubulointerstisial and/or vascular lesion (Martinez-Castelao et al. 2015).

Research in the use of traditional medicine, including herbs develops rapidly, as it is recommended by the World Health Organization (WHO) to maintain public health, to prevent and treat diseases, especially degenerative diseases, such as diabetes and cancer (Patwardhan 2005). There are many Indonesian native plants, which are used empirically to treat diabetes. Belimbing wuluh (Averrhoa bilimbi L.) is a medicinal plant belonging to the family of Oxalidaceae and mainly used as a folk medicine to treat DM, hypertension, and as an antimicrobial agent (Alhassan and Ahmed 2016). The extract of belimbing wuluh fruits with as dose of $750 \mathrm{mg} / \mathrm{kg}$ body weight (BW) was effective to lower blood glucose level in alloxan-induced diabetic rats (Candra 2012). Temulawak (Curcuma xanthorrhiza Roxb., Zingiberaceae) is used widely as traditional medicine to treat various diseases such as cancer, gastric, and diabetes 
(Hassan and Fadzilah 2014). The extract of temulawak rhizomes with a dose of $17.5 \mathrm{mg} / \mathrm{kg} \mathrm{BW}$ was effective to lower blood glucose level in alloxan-induced diabetic rats (Cahyani 2014).

Based on the potential hypoglycemic effect of the plants, this study aimed to evaluate the effect of ethanol extract combination of temulawak rhizomes and belimbing wuluh fruit in repairing kidney damage in streptozotocininduced diabetic Wistar rat. Streptozotocin (2-deoxy-2-[3(3-methyl-nitrosourea)-D-glucopyranose]) is a permanent diabetogenic agent which are toxic molecules that cause damage to pancreatic beta cells (Szkudelski 2001). Streptozotocin is widely used as a diabetogenic agent as it could be utilized at low doses and has a higher success rate (up to 95\%) than other inducers substances, such as alloxan (up to 70\%) (Junod et al. 1967). Streptozotocin-induced rats showed the occurrence of nephropathy, i.e. the expansion of glomerular extracellular matrix, thickening of the glomerular basal membrane, increased deposition of type IV collagen in mesangial cells (Gambaro et al. 1999), as well as necrosis in proximal tubules with the loss of brush borders (Zafar et al. 2009).

\section{MATERIALS AND METHODS}

\section{Collection and extraction of plant materials}

Belimbing wuluh (Averrhoa bilimbi L.) fruits were collected from Arboretum, University of Padjadjaran in Jatinangor, Sumedang, Indonesia, whereas temulawak (Curcuma xanthorrhiza Roxb.) rhizomes were collected from Indonesian Medicinal and Aromatic Crops Research Institute, Lembang, Bandung, Indonesia. The samples were identified in Taxonomy Laboratory in Department of Biology, Faculty of Mathematics and Natural Sciences, University of Padjadjaran. The samples were air-dried to a constant weight and blend to a coarse powder. The dried powder was soaked and macerated on $95 \%$ ethanol for 72 hours and every 24 hours the macerate was collected. The macerate was then evaporated using a rotary evaporator, resulting in a paste extract.

\section{Experimental animals}

Twenty-one male Wistar rat (160-180 g) were obtained from the animal house of the Laboratory of Biosystematics, Department of Biology, University of Padjadjaran, Indonesia. The rats were weighed and sorted into seven groups (Table 1) of three animals each so that their average weight approximately equal. They were housed in a standardized environmental condition and fed with piglet standard diets (CP-551, PT. Charoen Pokphand) and water which were given ad libitum. Animal care and handling conformed to accepted guidelines.

\section{Induction of diabetes and determination of blood glucose level}

After one-week of acclimatization period, the animals were fasted overnight, and their baseline fasting glucose levels were determined using a glucometer, by collecting blood via tail cut. Diabetes was induced by intra- peritoneally injecting six rat groups with streptozotocin (STZ) $(60 \mathrm{mg} / \mathrm{kg} \mathrm{BW})$ that was freshly prepared in $10 \mathrm{mM}$ citrate buffer solution, $\mathrm{pH} 4.5$. Negative control rats were injected with citrate buffer. To prevent hypoglycemia after STZ induction, the rats were supplemented with $10 \%$ sucrose solution for three days (Wu and Huan 2008). Three days after the administration of STZ, the rats were fasted again and the blood was collected from their tail cut to determine their fasting glucose levels. Rats which have glucose level more than $200 \mathrm{mg} / \mathrm{dL}$ were categorized as diabetic and used for the further experiments.

\section{Treatments of the extract}

Treatment for each of the group was showed in Table 2. The single or combined extract was administered orally using an intragastric tube for 21 days. The reference group were administered with glibenclamide at a dose of 0.45 $\mathrm{mg} / \mathrm{kg} \mathrm{BW}$, while the negative control group were administered $0.5 \%$ CMC solution. The animals were allowed to consume food and water ad libitum.

On the $22^{\text {nd }}$ days, after an overnight fast, the animals were weighed and sacrificed by cervical dislocation, and necropsies were done on them. Furthermore, kidneys were isolated from the rats and weighed, then examined for their morphology, i.e., the colors and textures. Last, the organs were preserved in Bouin's solution for histopathological examination. The kidneys were embedded in paraffin, and then sectioned, stained with hematoxylin and eosin, then were examined microscopically and analyzed using ImageJ software as described by Kotyk et al. (2015).

\section{Parameters observed}

\section{Relative weight observation of kidney organs}

Relative kidney weight was calculated using formula as follows (Mossa et al. 2015):

Relative kidney weight $(\%)=\frac{\text { Kidney weight }(\mathrm{g})}{\text { Body weight }(\mathrm{g})} \times 100 \%$

\section{Morphological observation of kidney organs}

The morphological observation of kidney organ is done directly (descriptive) with a scoring on color parameters and organ surface based on Leeson et al. (1996) as Table 1.

\section{Histological observation of kidney}

Histological observations of the kidneys were performed under a microscope by measuring the glomerular diameter, Bowman space, and percentage of proximal tubular necrosis in 5 different planes (four angles of the upper and lower and one center angle) using 400 times magnification with 1 replication (Rohmah 2014).

\section{Data analysis}

Results were expressed as mean \pm standard deviation (S.D). Statistical significance was analyzed using one-way ANOVA followed by Duncan multiple range test. P values less than 0.05 were considered significant. 
Table 1. Morphological kidney organ score

\begin{tabular}{|c|c|c|c|}
\hline \multirow{2}{*}{ Score } & \multicolumn{2}{|r|}{ Parameters } & \multirow{2}{*}{ Damage level } \\
\hline & Colors & Surface & \\
\hline 1 & Brownish red & Smooth and no abnormalities & Normal \\
\hline 2 & Brownish red & Coarse and there are abnormalities & Medium damaged \\
\hline 3 & Pale red & Coarse and there are abnormalities & Badly damaged \\
\hline
\end{tabular}

Table 2. Experimental design of the treatment

\begin{tabular}{lll}
\hline S/N & ID & Treatment \\
\hline A & Negative control (NC) & Citrate buffer and CMC 0.5\% \\
B & Positive control (PC) & STZ 60 mg/kg BW and CMC 0.5\% \\
C & T & STZ $60 \mathrm{mg} / \mathrm{kg} \mathrm{BW}$ and temulawak rhizomes extract $17.5 \mathrm{mg} / \mathrm{kg} \mathrm{BW}$ \\
D & BW & STZ $60 \mathrm{mg} / \mathrm{kg} \mathrm{BW}$ and belimbing wuluh fruit extract $750 \mathrm{mg} / \mathrm{kg} \mathrm{BW}$ \\
E & TBW1 & STZ $60 \mathrm{mg} / \mathrm{kg} \mathrm{BW}$ and combination extracts $767.5 \mathrm{mg} / \mathrm{kg} \mathrm{BW}$ \\
F & TBW2 & STZ $60 \mathrm{mg} / \mathrm{kg} \mathrm{BW}$ and combination extracts $383.75 \mathrm{mg} / \mathrm{kg} \mathrm{BW}$ \\
G & Reference & STZ $60 \mathrm{mg} / \mathrm{kg} \mathrm{BW}$ and glibenclamide $0.45 \mathrm{mg} / \mathrm{kg} \mathrm{BW}$ \\
\hline
\end{tabular}

\section{RESULTS AND DISCUSSION}

\section{Effect of treatments on relative weight of kidney}

The relative kidney weight showed the percentage of kidneys-to-body weight at the end of treatment period (Table 3). The result demonstrated that treatment of 60 $\mathrm{mg} / \mathrm{kg}$ BW STZ (PC), the single and the combined extracts of temulawak rhizomes and belimbing wuluh fruit (T, BW, TBW1, TBW2), as well as $0.45 \mathrm{mg} / \mathrm{kg} \mathrm{BW}$ glibenclamide (Reference) significantly increased the relative kidney weight of compared with the negative control (NC) $(\mathrm{p}<0.05)$. The treatment with $767.5 \mathrm{mg} / \mathrm{kg} \mathrm{BW}$ combined extract of temulawak rhizomes and belimbing wuluh fruit (TBW2) result in the highest relative weight of kidney.

\section{Effect of treatments on kidney morphology}

The aim of the morphological examination was to evaluate the effect of the treatments on the color and texture of kidneys (Figure 1). The result showed that treatment with $60 \mathrm{mg} / \mathrm{kg} \mathrm{BW} \mathrm{STZ} \mathrm{dose} \mathrm{(PC),} \mathrm{single} \mathrm{and}$ combined extracts of temulawak rhizomes and belimbing wuluh fruit (T, BW, TBW1, TBW2), as well as $0.45 \mathrm{mg} / \mathrm{kg}$ BW glibenclamide (reference), did not caused difference in the kidney morphology compared with the NC group.

\section{Effect of treatment on kidney histopathology}

The histopathological examinations of kidney included measurement of glomerulus diameter, Bowman's space width, and the number of necrotized proximal tubules (Figure 2, Table 4). The kidneys of NC (Figure 2A) and TBW2 rats (Figure 2.F) showed normal glomerulus, Bowman's space, and proximal tubules, whereas the kidneys of PC, T, BW, TBW1, and reference groups showed architectural damages, i.e., increase in glomerulus diameter and Bowman's space width, as well as increased number of proximal tubules with necrosis nuclei (Figure 2.B, C, D, E, and G).

Increasing of glomerulus diameter, Bowman's space width and number of necrotized proximal tubules in PC and reference groups was significantly different compared with NC $(p<0.05)$. The treatment of single or combined extract, however, significantly decreased the histopathological parameters compared with KP group $(\mathrm{P}<0.05)$, but did not different with $\mathrm{KN}$ group. Application of combined extract of temulawak rhizomes and belimbing wuluh fruit extracts at dose of $385.75 \mathrm{mg} / \mathrm{kg} \mathrm{BW}$ (TBW2) showed the lowest number of necrotized proximal tubules and significantly differed with other treatments $(\mathrm{p}<0.05)$.

\section{Discussion}

Organ weight is an important index of physiological and pathological status in animals. The relative organ weight is fundamental to diagnose whether the organ was exposed to the injury or not. Changes in kidney weight may reflect renal toxicity, tubular hypertrophy or chronic progressive nephropathy (Sellers et al., 2007). According to Al-Samawy (2012), the weight of the right kidney was $1.1 \mathrm{~g}$ and the left kidney is $0.96 \mathrm{~g}$, with mean about $1.06 \mathrm{~g}$ in albino rats. This study showed an increasing kidney weight and relative weight of kidney presumably due to directly or indirectly toxicity of streptozotocin which caused diabetic condition in rats. Both single and combined extract treatments of temulawak rhizomes and belimbing wuluh fruit did not affect relative weight of kidney possibly due to the insufficient treatment time. This result is supported by the research of Usoh et al. (2015), in which diabetic rats treated with a minimum dose $(200 \mathrm{mg} / \mathrm{kg} \mathrm{BW})$ of Gongronema latifolium and Ocimum gratissimum combined extract showed a marked difference in the relative kidney weight compared with the non-treated rats after 28 days of treatment. Glibenclamide treatment did not improve the relative weight of kidney due to drug pharmacokinetic changes in diabetic models. The reasons for these pharmacokinetic changes are diverse and complex, such as changes in transport, metabolism and drug elimination (Li et al. 2012). 
Table 3. Mean of relative weight of kidneys after 21 days of treatment

\begin{tabular}{llccc}
\hline ID & Treatment & $\begin{array}{c}\text { Body weight } \\
\text { (g) }\end{array}$ & $\begin{array}{c}\text { Kidneys } \\
\text { weight }(\mathbf{g})\end{array}$ & $\begin{array}{c}\text { Relative } \\
\text { weight of } \\
\text { kidney (\%) }\end{array}$ \\
\hline NC & Citrate buffer and CMC 0.5\% & $228.0 \pm 29.10$ & $1.750 \pm 0.24$ & $0.760 \pm 0.02^{\mathrm{a}}$ \\
PC & STZ 60 mg/kg BW and CMC 0.5\% & $179.0 \pm 18.52$ & $1.910 \pm 0.09$ & $1.067 \pm 0.08^{\mathrm{bc}}$ \\
T & STZ 60 mg/kg BW and temulawak rhizomes extract $17.5 \mathrm{mg} / \mathrm{kg} \mathrm{BW}$ & $179.0 \pm 4.35$ & $1.950 \pm 0.04$ & $1.087 \pm 0.04^{\mathrm{bc}}$ \\
BW & STZ 60 mg/kg BW and belimbing wuluh fruit extract 750 mg/kg BW & $172.6 \pm 21.93$ & $1.883 \pm 0.12$ & $1.090 \pm 0.07^{\mathrm{bc}}$ \\
TBW1 & STZ 60 mg/kg BW and combination extracts 767.5 $\mathrm{mg} / \mathrm{kg} \mathrm{BW}$ & $176.3 \pm 14.84$ & $2.026 \pm 0.10$ & $1.147 \pm 0.06^{\mathrm{c}}$ \\
TBW2 & STZ 60 mg/kg BW and combination extracts 383.75 mg/kg BW & $183.1 \pm 5.50$ & $1.886 \pm 0.04$ & $1.027 \pm 0.03^{\mathrm{b}}$ \\
Reference & STZ 60 mg/kg BW and glibenclamide $0.45 \mathrm{mg} / \mathrm{kg} \mathrm{BW}$ & $177.0 \pm 13.07$ & $1.913 \pm 0.04$ & $1.080 \pm 0.05^{\mathrm{bc}}$ \\
\hline
\end{tabular}

Note: The value is expressed as the mean \pm standard deviation $(n=3)$. Data were analyzed using one-way ANOVA followed by Duncan multiple range test. Difference alphabet in the same column showed P values less than 0.05 and considered significant

A

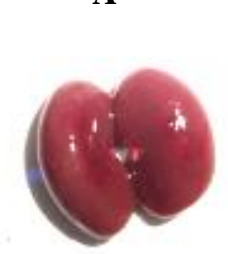

$\cdots$
$\mathbf{B}$

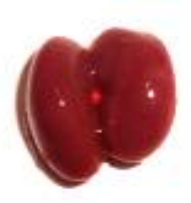

$\mathbf{E}$

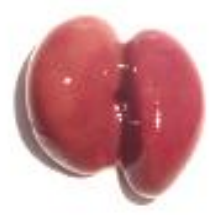

C

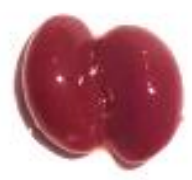

$\mathbf{F}$

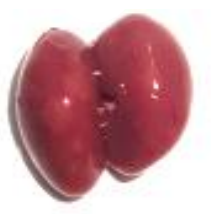

D

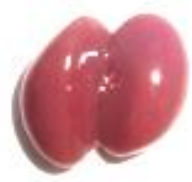

G

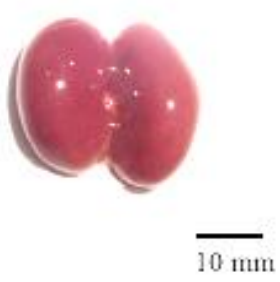

Figure 1. Morphology of kidneys after treatment for 21 days. Note: A. NC, B. PC, C. T, D. BW, E. TBW1, F. TBW2, G. Reference
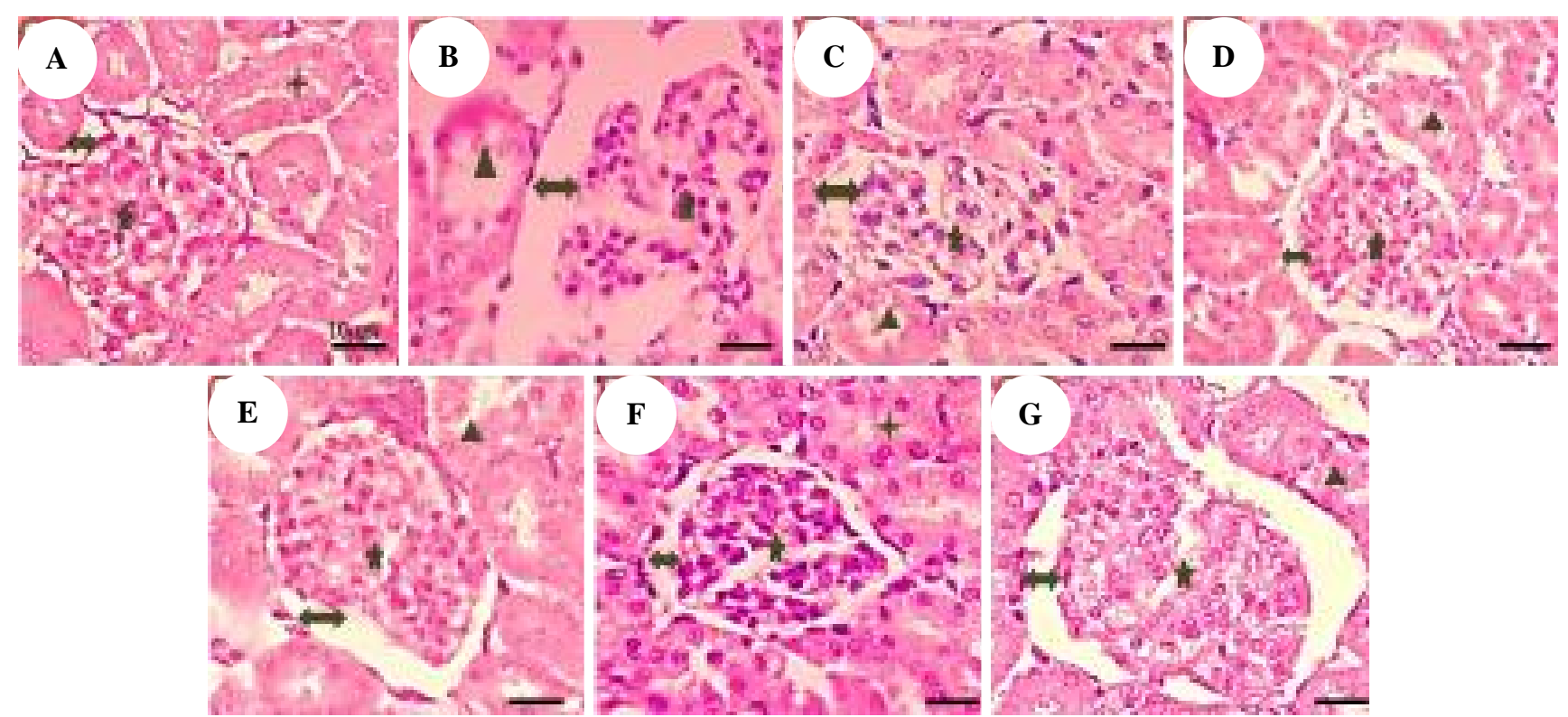

Figure 4. Photomicrograph of histological cross section of kidneys after treatment for 21 consecutive days. Heamatoxylin-Eosin stain. Note: A. NC, B. PC, C. T, D. BW, E. TBW1, F. TBW2, G. Reference. ( $)^{\prime}$ Glomerulus, $(\Leftrightarrow)$ Bowman’s space, $(\boldsymbol{\Delta})$ Normal proximal tubules, $(+)$ Necrotized proximal tubules, $(\bullet)$ Mesangial matrix expansion, $(\star)$ Glomerular basal membrane. 
Table 2. Histopathological parameters measurement of kidneys after 21 days of treatment

\begin{tabular}{llccc}
\hline ID & Treatment & $\begin{array}{c}\text { Glomerulus } \\
\text { diameter } \\
(\boldsymbol{\mu m})\end{array}$ & $\begin{array}{c}\text { Bowman's } \\
\text { space width } \\
(\boldsymbol{\mu m})\end{array}$ & $\begin{array}{c}\text { Number of } \\
\text { necrotized } \\
\text { proximal } \\
\text { tubules }\end{array}$ \\
\hline NC & Citrate buffer and CMC 0.5\% & $75.25 \pm 1.58^{\mathrm{a}}$ & $2.22 \pm 1.29^{\mathrm{a}}$ & $15.33 \pm 3.46^{\mathrm{a}}$ \\
PC & STZ 60 mg/kg BW and CMC 0.5\% & $92.20 \pm 4.72^{\mathrm{c}}$ & $12.09 \pm 2.68^{\mathrm{b}}$ & $64.33 \pm 3.05^{\mathrm{e}}$ \\
T & STZ 60 mg/kg BW and temulawak rhizomes extract $17.5 \mathrm{mg} / \mathrm{kg} \mathrm{BW}$ & $80.33 \pm 1.99^{\mathrm{ab}}$ & $5.28 \pm 2.74^{\mathrm{a}}$ & $56.33 \pm 2.88^{\mathrm{d}}$ \\
BW & STZ 60 mg/kg BW and belimbing wuluh fruit extract 750 mg/kg BW & $74.68 \pm 3.57^{\mathrm{a}}$ & $5.93 \pm 0.88^{\mathrm{a}}$ & $49.00 \pm 5.29^{\mathrm{c}}$ \\
TBW1 & STZ 60 mg/kg BW and combination extracts $767.5 \mathrm{mg} / \mathrm{kg} \mathrm{BW}$ & $78.42 \pm 1.79^{\mathrm{ab}}$ & $6.14 \pm 2.42^{\mathrm{a}}$ & $51.66 \pm 5.50^{\text {cd }}$ \\
TBW2 & STZ 60 mg/kg BW and combination extracts 383.75 mg/kg BW & $77.95 \pm 4.38^{\mathrm{ab}}$ & $5.06 \pm 0.20^{\mathrm{a}}$ & $34.00 \pm 1.00^{\mathrm{b}}$ \\
Reference & STZ 60 mg/kg BW and glibenclamide $0.45 \mathrm{mg} / \mathrm{kg} \mathrm{BW}$ & $85.64 \pm 7.77^{\mathrm{bc}}$ & $10.98 \pm 1.72^{\mathrm{b}}$ & $63.66 \pm 5.68^{\mathrm{e}}$ \\
\hline
\end{tabular}

Note: The value is expressed as mean \pm standard deviation $(n=3)$. Data were analyzed using one-way ANOVA followed by Duncan multiple range test. Different alphabets in the same column indicate $\mathrm{P}<0.05$ and was considered significantly different.

Changes in organ weights should always be interpreted in conjunction with morphological and histopathological findings because of the inherent variability. All treatments in this study did not affect the kidney morphology, which shown a bean-shaped and dark-red bodies with smooth and possess convex and concave borders. The results of this study is agrees with Al-Samawy (2012).

The histopathological examination result in this study agrees with Zafar and Naqvi (2010) who found that the relative kidney weight in STZ-induced rat for 12 weeks was significantly higher than that of the non-induced rat. Vallon and Thomson (2012) stated that diabetes mellitus affected the kidneys gradually. The onset of damage in diabetic is marked by the increase in kidney size and the glomerular filtration rate (GFR), leading to the development of kidney failure in diabetic diseases.

The mean of glomerular diameter in diabetic rats was greater than that of non-diabetic rats indicates that streptozotocin induced glomerular enlargement (hypertrophy) in kidney. Glomerular hypertrophy is an initial event in the development of glomerular damage, which occurs as a result of the expansion of mesangial matrix and the thickening of the glomerular basement membrane (Zafar et al. 2009). The expansion of mesangial matrix and the thickening of glomerular membrane were also observed in this study. Glomerular hypertrophy associated with the increase in GFR which is caused by the increase of plasma flow and the pressure of glomerular capillary hydrostatic. Glomerular hemodynamic changes are associated with growth processes (O'Bryan and Hostetter, 1997). Growth factors and cytokines involved in the mesangial or hypertensive expansion, such as Transforming growth factor- $\beta 1$ (TGF $-\beta 1$ ) and angiotensin II, are found to participate in the development of diabetic nephropathy (Lehman and Schleicher 2000).

In this study, the Bowman's space in kidneys of diabetic rats was wider than of non-diabetic rats. This result is similar to the results of Kotyk et al. (2015) that reported the widening of Bowman's space in rat upon fructose treatment. BoTman's space widening is caused by the expansion of the Bowman capsule when glucose enters kidneys (Zhang et al. 2015), which also associated with increased absorption and accumulation of glycogen in kidneys (Mahood 2012) which caused nephropathy in diabetic disease model.

The percentage of proximal tubular with necrosis nuclei in diabetic rats also greater than in the non-diabetic rats. Necrosis of proximal tubules is indicated by the brush border deficiency, epithelial cell changes in the proximal tubules (such as closed lumen caused by swollen cytoplasm), cryolysis (dissolved chromatin in the cell nucleus) and picnosis (thickening and shrinking of the cell nucleus due to chromosomal dissolution and condensation). This finding is consistent with the result of Zafar et al. (2009) that found that necrosis with loss of brush borders in the proximal tubular area occurred in the kidneys of rats induced with $45 \mathrm{mg} / \mathrm{kg}$ BW STZ. STZ-induced kidney damage is presumably mediated by Glut2 uptake in the proximal tubular cells, which stimulates tubular necrosis and then alters kidney function (Tay et al. 2005).

Treatment with single extract of temulawak at dose of $17,5 \mathrm{mg} / \mathrm{kg}$ BW showed improvement in kidney histological structure as indicated by decreased of glomerular diameter, narrowed of Bowman space, and decreased of the necrotized proximal tubules. Temulawak contains potent curcumin that serves as an antioxidant which capable of improving kidney damage caused by reactive oxygen species (ROS). However, this treatment has a less effect in improving kidney structure compared with other treatments. The kidneys structure upon treatment with single extract of belimbing wuluh at dose of 750 $\mathrm{mg} / \mathrm{kg} \mathrm{BW}(\mathrm{BW})$ better than the diabetic and reference groups. The fruit of Belimbing wuluh contains saponin and flavonoid. Both compounds are known to be helpful in improving kidney condition as shown by the study of Firdous et al. (2009) who stated that saponin from Momordica cymbalaria extract increased insulin secretion by regenerating pancreatic beta cells in streptozotocininduced diabetic rat. An increasing insulin level has a role in glucose metabolism, so that the blood entering the kidney was normal and in turn, this would facilitate the process of kidney filtration.

The histological structure of kidney after the combined extract treatment with temulawak and belimbing wuluh at 
dose of 767.5 and $383.75 \mathrm{mg} / \mathrm{kg} \mathrm{BW}$ showed improvement compared with diabetic rats, although the better result showed by the less dosage. Active compounds in the combined extract of temulawak and belimbing wuluh was assumed work synergistically, result in increasing of effectiveness of those compounds in repairing kidney histological damage caused by STZ toxicity. This result is in agrees with Jain et al. (2011) which found that a combination of several spices with green tea could synergistically increased antioxidant activity to treat diabetic disesase. Antioxidants can capture free radicals by releasing hydrogen atoms from their hydroxyl groups. Giving hydrogen atoms causes free radicals to stabilize and reducing their activity which cause damage the lipids, proteins, and DNA and induced cell damage (Manabe et al. 2007).

This study showed that the treatment combined extract of temulawak rhizome and belimbing wuluh fruit at dose of $383,75 \mathrm{mg} / \mathrm{kg} \mathrm{BW}$ could improve histological damages of kidney as indicated by the decreasing of the glomerular diameter, Bowman space width, and the percentage of necrotized proximal tubules in diabetic rats induced by streptozotocin. This treatment is more effective than the single or combined extract treatment at higher dosage in improving histological damage of kidneys and recommended for further investigation, including toxicity test to provide scientific justification for their traditional use and prove that they are safe and efficacious.

\section{ACKNOWLEDGEMENTS}

This research was supported by Directorate of Research, Technology and Higher Education of the Republic of Indonesia. In this opportunity, we gratefully acknowledge the financial support of PUPT budget year 2017.

\section{REFERENCES}

Alhassan AM, Ahmed QU. 2016. Averrhoa bilimbi Linn.: A review of its ethnomedicinal uses, phytochemistry, and pharmacology. J Pharm Bioall Sci 8: 265-271.

Al-Samawy, E.R.M. 2012. Morphological and Histological study of the kidneys on the Albino rats. Al-Anbar J. Vet. Sci., 5 (1), 115-119.

Artanti P, Masdar H, Rosdiana D. 2015. The incidence of undiagnosed diabetes mellitus in Pekanbaru city. Jom FK. 2 (2): 1. [Indonesian]

Cahyani MN. 2014. Effect of ethanol extract ginger rhizome (Curcuma xanthorrizha Roxb.) against blood glucose levels of white rats (Rattus norvegicus) alloxan -induced wistar strains. [Hon. Thesis] Universitas Tanjungpura, Pontianak. [Indonesian]

Candra S, Kusmiyati DK, Wiyoko YLA. 2012. Effect of fruit extract of Belimbing Wuluh (Averrhoa bilimbi L.) on reduction of blood glucose levels of Wistar Rats induced by alloxan. Jurnal Kedokteran $\begin{array}{llll}\text { Diponegoro } & 1 & \text { (1). } & \mathrm{http}\end{array}$ s1.undip.ac.id/index.php/medico/article/view/1446. [Indonesian]

Cooke DW, Plotnick L. 2008. Type 1 Diabetes Mellitus in pediatrics. Pediatrics Rev 29: 374-384
Gambaro G, Angelo AD, Prete DD, Coel M, Garbisa S. 1999. Mesengial cell proliferation in long term streptozotocin induced diabetes mellitus in the rat and the renoprotective activity of heparin. Am J Nephrol 19 (4): 530-534.

Hassan FI, Fadzilah AAM. 2014. Anti-diabetic effect of Curcuma Xanthorrhiza on Adipogenesis of 3T3-L1 Preadipocyte. Regener Res 3 (2): 105-107

Junod A, Lambert AE, Orci L, Pictet R, Gonet AE, Renold AE. 1967. Studies of the diabetogenic action of streptozotocin. Proc Soc Exp Biol Med 126: 201-205.

Kotyk T, Dey N, Ashour AS, Timar DB, Chakraborty S, Ashour AS, Tavares JMRS. 2015. Measurement of the glomerulus diameter and Bowman's space thickness of renal albino rats. Comput Meth Prog Biomed 126: 143-153.

Lehmann R, Schleicher ED. 2000. Molecular mechanism of diabetic nephropathy. Clin Chim Acta 297: 135-144.

Li, C, Shang D, Wang Y, Li J, Han J, Wang S, Yao Q, Wang Y. 2012. Characterizing the network of drugs and their affected metabolic sub pathways. PLoS ONE 7(10): e47326. DOI: 10.1371/journal.pone.0047326

Mahood AKS. 2012. Histological study of the effect of nigella sativa on diabetic nephropathy in rats. Tirkit Med J 18 (2): 154-168.

Martínez-Castelao A, JF Navarro-González, JL Gómiz, and F de Alvaro. 2015. The concept and the epidemiology of diabetic nephropathy have changed in recent years. J. Clin. Med. 4: 1207-1216. DOI: $10.3390 / \mathrm{jcm} 4061207$.

O'Bryan GT, and TH Hostetter. 1997. The renal hemodynamic basis of diabetic nephropathy. Semin Nephrol 17: 93-100.

Patwardhan B. 2005. Traditional Medicine: Modern Approach for Affordable Global Health. World Health Organization (WHO) and Commission on Intellectual Property, Innovation, and Public Health (CIPIH) Study Nine on TM, World Health Organization, Geneva.

Ragbetli C, Ceylan E. 2010. Effect of Streptozotocin on biochemical parameters in rats. Asian J Chem 22 (3): 2375.

Ritz E, Keller C, Kristian HB. 2000. Nephropathy of Type II Diabetes Melitus. Nephrol Dial Transplant 11 [Suppl 9]: 38-44

Ritz E, Zeng X. 2011. Diabetic nephropathy - epidemiology in Asia and the current state of treatment. Indian J Nephrol 21: 75-84.

Sellers RS, Morton D, Michael B, Roome N, Johnson JK, Yano BL, Perry R, Schafer K. 2007. Society of Toxicologic Pathology position paper: organ weight recommendations for toxicology studies. Toxicol. Pathol. 35 (5), 751-755.

Szkudelski T. 2001. The mechanism of alloxan and streptozotocin action in $\beta$ cells of the rat pancreas. Physiol Res 50: 536-54.

Tay YC, Wang Y, Karaitis L, Rangan GK, Zhang C, Harris DCH. 2005. Can murine diabetic nephropathy be separate from superimposed acute renal failure. Kidney Intl 63: 391-398.

Usoh IF, Akpanyuyng EO. 2015. Leaves extract of Gongronema latifolium and Ocimum gratissimum offer synergy on organ weights alleviation and pancreatic resurgence against streptozotocin diabetic rats. J Innov Pharmaceut Biol Sci 2 (4): 522-536.

Vallon V, Thomson SC. 2012. Renal function in diabetic disease models: the tubular system in the pathophysiology of diabetic kidney. Ann Rev Physiol 74: 1-27.

WHO. 1999. Definition, Diagnosis, and Classification of Diabetes Mellitus and Its Complications. World Health Organization, Geneva.

WHO. 2016. About Diabetes: Complications of Diabetes. World Health Organization, Geneva.

Wu KK, Huan Y. 2008. Streptozotocin-Induced Diabetic Models in Mice and Rats. Curr Protoc Pharmacol 5. DOI: 10.1002/0471141755.ph0547s40.

Zafar M, Naqvi SN, Ahmed M, Kaimkhani ZA. 2009. Altered kidney morphology and enzymes in streptozotocin induced diabitc rats. Intl $\mathbf{J}$ Morphol 27 (3): 783-790.

Zhang S, Xu H, Yu X, Wang Y, Sun F, Sui D. 2015. Simvastatin ameliorates low-dose streptozotocin induced type 2 diabetic nepropathy in an experimental rat model. Intl J Clin Exp Med 8 (4): 6388-6396. 